\title{
最近の歯学
}

\section{5. 歯科薬理}

\section{Chlorpromazine のラット切歯象牙質形成に及洼す作用}

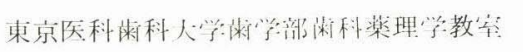

Chlorpromazine (以ト CPZ と略す) は major tranquilizer として広く精神分裂病や躁病の治療に用いられ ており，その中枢神経系に対する薬理作用に関しては数 多くの研究が行われているが，硬組織形成に及ぼす作用 に関する知見は少ない。今回われわれはラット切来像才 質形成に及活す CPZの作用を検索する目的で基儊的な 乎験を行い若干の知見を得たのでここにその概裂を紹 介寸る。平均体重 $120 \mathrm{~g}$ の Wistar 系雄性ラット35匹を 5 匹ずつ7群に分け，その5ちの5群にCPZをそれを 水 $5,10,20,40,80 \mathrm{mg} / \mathrm{kg}$ の投与去で皮卜注射を行。 た。1群のラットには生理食盍液を投尗して対照群とし た。また CPZの大量投与群においてては, 顷盰間持続す る睡服作用が発現して掑食不能となるため， 1 群のラッ

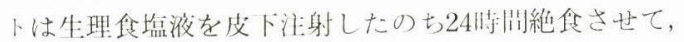

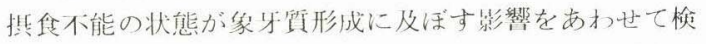
邻した。1 Hの象牙質形成星を叶測する日的で EDTA 釗 の皮卜注射による硬組織内時刻描記法を用いた。すなわ ち，EDTA 鉛を $30 \mathrm{mg} / \mathrm{kg}$ の投与量で 24 時間䦌隔で 5 回 支下注射し，その 2 回日の注射直後に CPZ あるいは恔 理食塩液を投与して, 薬物投与 6 日後にラットを着殺し て, 常法に徉って切片を作製した。象牙質の形成量は Leit $z$ 社製画像解析装置 TAS plusにより計測を行った。 また，非脱灭研磨切片を作製し contact microradiograph (CMR) を撮影した。その結果，24侍間絶食群では象牙 犋形成に変化は認められなかったが，CPZは投与後24侍 间の象牙質形成量を用量一依存性に抑制することがホさ わた（図 1)。薬物投与後に形成された象牙質では，史 ず幅の狭い, hematoxylin 濃染層が出現し, その後 hematoxylin にほとんど染色されない層が形成される像が認 められた。また CMR 像では CPZ 投与後, 象牙質のイ

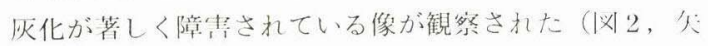
印)。こ扎らの所思から CPZ が象牙芽細胞の機能に抑例

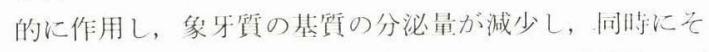
の基質の組織化学的性質にも变化を牛じて, 取終的に位 灰化が著しく障書された象牙質が形成されたものと推察
俣木 志朗，若松 大成，大谷 息一，小椋 秀完

される。

ラットに皮下注射する場合の CPZ の LD 50 は5 $42 \mathrm{mg}$ / $\mathrm{kg}^{-1)}$ であり, 今回の実験で用いた投与量で著しい象牙質 形成障青が惹起されたことは重要な知見と思われる。最 近 CPZが in vivo でラットの骨形成を抑制し, さらに 骨吸収も抑制する可能性も示唆されているが2), CPZの 作用機序については明らかにされていない。CPZには 微小管阴害作用 ${ }^{3}$ ，および抗 calmodulin 作用 ${ }^{4)}$ があり骨 芽細胞や象牙芽細胞など分泌型の細胞に, より強い作 用が発現する可能性も考えられる。今後さらに検索をす すか CPZ の硬組䋞に及ぼす作用を研究していきたい。

\section{文献}

1) Barnes, C. D. and Eltherington, L. G. : Drug dosage in laboratory animals. University of California Press, 1964.

2) Komoda, T., et al. : Chlorpromazine alters bone metabolism of rat in vivo. Calcif. Tissue Int. 42 : 58-62, 1988.

3) Dustin, P. : Microtubules. p. 210, Springer-Verlag, 1978.

4) 日高弘義編：阻害剂研究法. 共立出版, 1985.

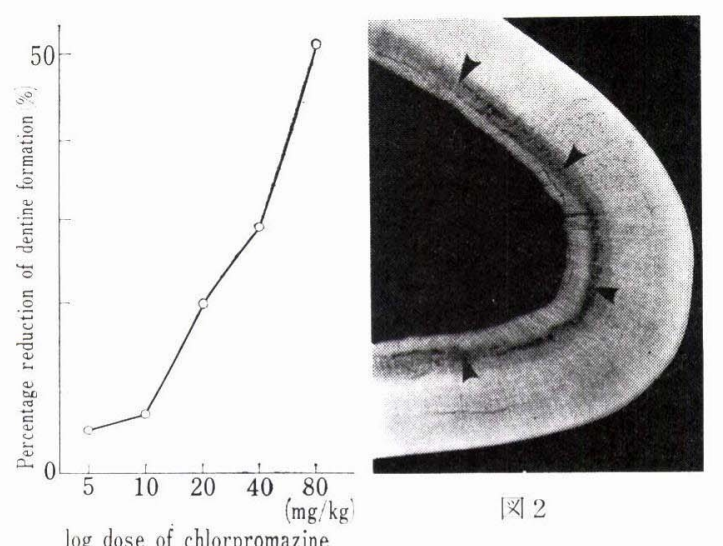

$\log$ dose of chlorpromazine

闵 1 